\title{
Tumor-infiltrating Iymphocytes predict prognosis of breast cancer patients treated with anti-Her-2 therapy
}

\author{
Tan-Huan Chen ${ }^{1,2, *, * *}$, Ying-Chun Zhang ${ }^{3, *}$, Yu-Ting Tan ${ }^{4, *}$, Xin An ${ }^{2, * *}$, Cong Xue ${ }^{2, * *}$, \\ Ying-Fei Deng ${ }^{2, * *}$, Wei Yang ${ }^{2, * *}$, Xia Yuan ${ }^{1, * *}$, Yan-Xia Shi2,** \\ ${ }^{1}$ Department of Medical Oncology, Affiliated Hui Zhou Municipal Central Hospital \& Training Base for Masters of Sun Yat-Sen \\ Memorial Hospital, Sun Yat-Sen University, Huicheng District, Huizhou, Guangdong 516000, P. R. China \\ ${ }^{2}$ Department of Medical Oncology, Sun Yat-Sen University Cancer Center, Guangzhou, Guangdong 510000, P.R. China \\ ${ }^{3}$ Department of Pathology, Sun Yat-Sen University Cancer Center, Guangzhou, Guangdong 510000, P.R. China \\ ${ }^{4}$ Department of Radiotherapy, Sun Yat-Sen University Cancer Center, Guangzhou, Guangdong 510000, P.R. China \\ *These authors have contributed equally to this work \\ *** These corporations have contributed equally to this work \\ Correspondence to: Yan-Xia Shi, email: shiyx@sysucc.org.cn \\ Xia Yuan, email: yuanxia71@hotmail.com
}

Keywords: TILs, anti-Her-2 therapy, breast cancer, prognosis

Received: June 21,2016 Accepted: November 21,2016 Published: December 23, 2016

\section{ABSTRACT}

Purpose: Infiltration of tumor associated lymphocytes and count of its different phenotypes are potentially new independent predictor of prognosis in breast cancer. However, research related to it is less reported in breast cancer patients treated with anti-Her-2 therapy. Thus, we evaluated the relationship between survival and tumor infiltrating lymphocytes including its different phenotypes in tumors of such patients.

Methods: Between 1999 and 2010, 98 patients diagnosed with primary breast cancer and treated with anti-Her-2 therapy at Sun-Yat-Sen University Cancer Center were included in the study. Biopsy specimens were collected post-operation but before chemotherapy. Tumor infiltrating lymphocytes as well as its FOXP3+, CD68+, IL-17+ phenotypes in both intratumoral and stromal sites and expression of FOXP3 in cancer cells were assessed.

Results: Median follow-up time of 98 patients was 83.3 months (range 7.4201 months). It suggested that patients with high stromal infiltration of TILs, lower count of FOXP3+ Tregs and CD68+ MQ in stromal site, and high expression of FOXP3 in cancer cells had longer survival of OS. In multivariate Cox regression analysis, high count of intratumoral CD68+ MQ [HR: $2.70(1.00-7.31) ; p=0.050$ ] and high expression of FOXP3 in cancer cells [HR: $0.29(0.09-0.91) ; p=0.034$ ] were independent prognostic factors for overall survival.

Conclusions: Tumor infiltrating lymphocytes as well as its FOXP3+, CD68+ phenotypes in stromal site, and expression of FOXP3 in cancer cells were significantly associated with OS, suggesting that they can be used as important pathological factor predicting prognosis of breast cancer patients treated with anti-Her-2 therapy.

\section{INTRODUCTION}

Breast cancer was the mostly diagnosed tumor for women worldwide now, and incidence of it kept on increasing year by year. For tumor related death of women, breast cancer was the second causing disease too [1]. In all of the breast cancer patients, $25-30 \%$ were with
Her-2 (human epidermal growth factor receptor-2) protooncogene amplification or excessive expression of Her-2 protein. Her-2 status was also one of the most important prognostic factor in breast cancer and overexpression with Her-2 was associated with disease progress and prognosis of patients [2]. Anti-Her-2 therapy which was mainly represented by trastuzumab can not only significantly 
inhibit tumor growth but also synergize with traditional cytotoxic chemotherapy to reduce recurrence risk of operable breast cancer patients by $46 \%$ and prolonged the OS (overall survival) of advanced breast cancer patients by $5-15$ months [3].

Being the basis of Her-2 positive breast cancer treatment, trastuzumab was a humanized monoclonal antibody targeting at extracellular domain of Her-2, and previous studies demonstrated blocking Her-2 mediated signaling pathway was the main mechanism of its efficacy. However, the recent research found that trastuzumab can induce antibody dependent cellular cytotoxicity (ADCC) and play an immunomodulatory role in the course of the anti-Her2 therapy which were crucial to its efficacy $[4,5]$. Meanwhile, on the tumor response to chemotherapy, immune cells, especially tumor infiltrating lymphocytes (TILs) in tumor microenvironment and its potential role attracted more and more attention [6]. More and more evidence showed that the interaction between these immune cells and tumor was important for the course and progress of tumor [7] and related to efficacy of trastuzumab [8-12]. Several studies also indicated that TILs can predict better response of higher pathologic complete response (pCR) rate to chemotherapy and antiHer-2 therapy in breast cancer [6, 13-17].

Tumor-infiltrating lymphocytes(TILs) were white blood cells that left the bloodstream and migrated into a tumor. They were mononuclear immune cells, a mix of different types of cells (i.e., T cells, B cells, NK cells, macrophages) in variable proportions [18]. As the natural anti-tumor immune barrier of host, monocytemacrophage $(\mathrm{M} \varphi)$ were important component of TILs. In normal tissues, $\mathrm{M} \varphi$ showed spontaneous anti-tumor effect $[19,20]$. As the most abundant antigen-presenting cells in solid tumor, $\mathrm{M} \varphi$ expressed $\mathrm{FC} \gamma \mathrm{R}$ (Fc-gamma receptor) on its surface and by combining with FC $\gamma \mathrm{R}$ trastuzumab can induce ADCC to surpress tumor [21]. However, there was another unique subtype of $\mathrm{M} \varphi$ described as M2 which can suppress antitumor immunity and promote tumor progression $[22,23]$. Thus, $\mathrm{M} \varphi$ were a highly heterogeneous group of cells that maybe play different functions in different tumor microenvironment and therefore efficacy of trastuzumab may varied with different type of $\mathrm{M} \varphi$.

Trastuzumab can induce the production of endogenous anti-Her-2 antibody and antigen-specific CD4+ $\mathrm{T}$ cells by activating antigen-specific humoral immunity in vivo. Clare Taylor et al reported after 8 weeks of treatment combining trastuzumab with chemotherapy, endogenous anti-Her-2 antibody and antigen-specific CD4 $+\mathrm{T}$ cells can be detected in the peripheral blood circulation, and this immune response can be sustained through 15 weeks and brought benefit to patients with prolonged PFS (progression free survival) [24]. Besides, CD8+ T cell mediated cellular immunity also played an important role in anti-tumor immunology process through its cytotoxic effect. And Park S et al reported crucial role of $\mathrm{T}$ cell in trastuzumab treatment [8]. It showed that efficacy for inhibiting tumor growth of anti-Her-2 antibody weakened greatly in the mice lack of T cells and elimination of CD $8+T$ cells in wild type mice significant promoted tumor recurrence. On the contrary, in tumor tissue of mice and patients treated with anti-Her-2 antibodies, T cells, especially CD8+ T cells can be increasingly detected. And these existing and more effector and memory $\mathrm{T}$ cells maybe make the mice to tolerate higher doses of tumor cells inoculation thereafter. Moreover, in Rag-/- immunodeficiency mice with specifical elimination of $\mathrm{T}$ and $\mathrm{B}$ cells, curative effect of trastuzumab was very weak, indicating the mechanism of effect for trastuzumab largely depended on humoral immunity and cellular immunity of host.

In vivo, both $\mathrm{CD} 4+\mathrm{T}$ and $\mathrm{CD} 8+\mathrm{T}$ cells were regulated by $\mathrm{CD} 4+, \mathrm{CD} 25+$ regulatory $\mathrm{T}$ cells (Tregs) whose specific marker was FOXP3 (forkhead box P3) [25]. $\mathrm{M \varphi}$ and tumor in situ can secrete IL-10 to recruit Tregs to tumor site [26] indicating that $\mathrm{M \varphi}$ may affect the number of FOXP3+ Tregs by cytokines. Tregs would increase in tumor site or be induced into CD4+, CD25+ T cells by tumor-associated DCs (dendritic cells) [27-29] and FOXP3 gene played a critical role in Tregs' differentiation, development and maintenance of function during this process [30].

Th1 (T helper 1 cells) produced IFN- $\gamma$ (interferon gamma) to promote anti-microbial and anti-tumor response, and Tregs suppressed the immune response of $\mathrm{T}$ cells in both physiological and pathological state [31, 32]. Another new CD4+ T helper cells can produce IL17 was defined as Th17 (T helper 17 cells), and most of the inflammatory damage which before was thought to be caused by Th1 response now was found to be caused by IL-17 and IL-23, which were important cytokines in vivo that can support Th17 reaction $[33,34]$. However, the role of Th17 in human tumor progression was still not clear.

Studies also reported that trastuzumab can reduce Tregs in peripheral circulation and therefore broke the balance between Tregs and Th17 [35] so that eliminated the deactivated status of immune system to promote the host's anti-tumor immunity. Therefore, anti-tumor effect of trastuzumab may be a complex but orderly process which firstly released detrimental factors by blocking Her-2 mediated signal transduction pathways and then activated hosts' innate and adaptive immune response including humoral and cellular immunity to control and eliminate tumors.

Many researchers explored prognostic value of Her-2 gene amplification and protein overexpression to anti-Her-2 therapy. However, Perez et al found 174 patients who were Her-2 negative detected by IHC (immunohistochemistry) and FISH (fluorescence in situ hybridization) also benefited from anti-Her-2 therapy (DFS HR 0.34; 95\% CI, 0.14$0.80 ; \mathrm{P}=0.014$ ) [36]. Besides, in pathways linked to Her-2, 
molecular and genetic factors such as NRGs (neuregulins) [37], IGF-1R(insulin-like growth factor 1 receptor) [38], PI3K (phosphoinositide 3-kinase), PTEN (phosphatase and tensin homolog), mTOR (mechanistic target of rapamycin) and NF- $\mathrm{KB}$ (nuclear factor kappa-light-chain-enhancer of activated B cells) [39] were all potentially or provenly associated with the signal transduction pathway of Her-2 and consequently therapeutic effect of anti-Her-2 therapy. Nevertheless, predictive value of these factors to prognosis reported by literatures was inconsistent, and therefore was far away from clinical application.

In view of the value of immune factors for antiHer-2 therapy, the factors that affect the immune response such as TILs, are likely to influence the curative effect of anti-Her-2 therapy $[6,40]$. Studies indicated that including affinity and polymorphism of $\mathrm{FC} \gamma \mathrm{R}$ receptor on immune effector cells [21], host immune status and local immune status around tumor such as ratio of immunosuppressive regulatory cells around tumor or in peripheral circulation which is represented by the ratio of Tregs/Th17, $\mathrm{pDC} /$ mDC (plasmacytoid dendritic cell/ myeloid dendritic cell), etc [41], and chemotherapeutic agents used in combination with trastuzumab [8], all these factors can affect the immune response. As a result, whether these baseline immune index and strength of host's adaptive immune response can work as a predictor of efficacy of anti-Her-2 therapy attracted more interest and attention, taking into account its crucial significance for patients without measurable lesions and received adjuvant therapy.

In conclusion, in this study, by detecting quantity and distribution of FOXP3+ Tregs, CD68+ M $\varphi$ and IL-17+ Th17 in the tumor microenvironment as well as potential relationship between them, we explored the value of these factor to predict efficacy of anti-Her-2 therapy, attempting to guide treatment options for anti-Her-2 therapy.

\section{RESULTS}

\section{Patient characteristics}

A total of 98 patients treated with anti-Her-2 therapy were included in the present study. The median age at diagnosis was 47 years (range, 26-76 years) (Table 1). All of the patients were female and median follow-up time is 83.3 months (range 7.4-201 months). Although 14 patients were Her-2/neu negative by IHC (FISH test result unavailable) or unspecified (both IHC and FISH results unavailable), we still included them at last according to their records of treatment with anti-Her-2 therapy (trastuzumab). Clinical characteristics of 98 patients were showed in Table 1.

\section{Histopathological and immunohistochemical evaluation}

In $98 \mathrm{HE}$ stained breast cancer tissue samples: Median TILs percent of intratumoral site was 3\% (range
$0.5 \%-90 \%$ ), with 16 patients $\geq 10 \%$ and 82 patients $<10 \%$. Median TILs percent in stromal site was $10 \%$ (range $2.5 \%-90 \%$ ), with 57 patients $\geq 10 \%$ and 42 patients $<10 \%$. Richness and absence of TILs in intratumoral and stromal sites by HE staining were showed in Figure 1.

For IHC staining, the positive expression of FOXP3+ Tregs was pale brown in cell nucleus with the median value of positive cells count in intratumoral site 6.8/HPF (range 3-18.3/HPF) and stromal site 17.2/ HPF (range 6-94.7/HPF). Infiltration of FOXP3+ Tregs in intratumoral and stromal site were showed in Figure 2. The positive expression of $\mathrm{CD} 68+\mathrm{M} \varphi$ was brown in cytoplasm with the median value of positive cells count in intertumoral site 66/HPF (range 12-98.7/ $\mathrm{HPF}$ ) and stromal site 81.3/HPF (range 26.3-131.3/HPF). Infiltration of $\mathrm{CD} 68+\mathrm{M} \varphi$ in intratumoral and stromal site were showed in Figure 2. The positive expression of IL$7+$ Th17 was pale brown in cytoplasm with the median value of positive cells count in intratumoral site $1.3 / \mathrm{HPF}$ (range 0.3-9.3/HPF) and stromal site 4.3/HPF (range 0.713.7/HPF). Infiltration of IL-7+ Th17 in intratumoral and stromal site were showed in Figure 2. The results of FOXP3+ Tregs, CD68+ M $\varphi$ and IL-17+ Th17 counts were presented in Supplementary Table S1.

In addition to TILs, expression of FOXP3 was also found in tumor cells and two independent reviewers evaluated it by percentage of positive tumor cells of total tumor cells. Average of two reviewers' value was the final result and expression percentage $>$ median was defined as high expression of FOXP3 in tumor cells. Median of FOXP3 expression in tumor cells was 3\% (range 0-85\%) with 39 patients high expression and 59 patients low expression. Expression of FOXP3 in cancer cells was showed in Figure 2. Correlation between infiltration of TILs, three different phenotypes of TILs and clinicopathological features of 98 patients was showed in Table 2.

\section{Survival analysis}

In survival analysis, with 16 patients $\geq 10 \%$ linked to survival of 130.9 months (range 110.0-151.8 months) and 82 patients $<10 \%$ linked to survival of 120.7 months (range 101.4-140.1 months), patients with high infiltration of intratumoral TILs just tended to had longer OS than patients with low, because of the p-value of 0.065 ; On the other side, with 57 patients $\geq 10 \%$ linked to survival of 138.0 months (range 116.5-159.4 months) and 41 patients $<10 \%$ linked to survival of 96.2 months (range 78.1-114.2 months), patients with high infiltration of stromal TILs also had longer OS than patients with low, and data of two groups are statistically significant with $\mathrm{p}=0.041$ (Figure 3 ).

Patients with a lower number of FOXP3 + Tregs in stromal site had significantly longer OS than patients with a higher number of stromal FOXP3 + Tregs (142.6 (119.5165.6) vs. 81.3(70.1-92.6) months; $\mathrm{p}=0.041)$. However, 
Table 1: Characteristics of 98 breast cancer patients treated with anti-Her-2 therapy

\begin{tabular}{|c|c|}
\hline Characteristic & n (\%) \\
\hline \multicolumn{2}{|c|}{ Age at diagnosis, years } \\
\hline Median age & 47 (Range 26 76) \\
\hline$>50$ & $41(42 \%)$ \\
\hline$\leq 50$ & $57(58 \%)$ \\
\hline \multicolumn{2}{|c|}{ Menopausal status } \\
\hline Pre & $56(57 \%)$ \\
\hline Post & $42(43 \%)$ \\
\hline \multicolumn{2}{|l|}{ Tumor size } \\
\hline$>2 \mathrm{~cm}$ & $51(52 \%)$ \\
\hline$\leq 2 \mathrm{~cm}$ & $32(33 \%)$ \\
\hline Unavailable & $15(15 \%)$ \\
\hline \multicolumn{2}{|l|}{ Nodal status } \\
\hline $\mathrm{N}_{0}$ & $25(26 \%)$ \\
\hline $\mathrm{N}_{1}$ & $29(30 \%)$ \\
\hline $\mathrm{N}_{2}$ & $22(22 \%)$ \\
\hline $\mathrm{N}_{3}$ & $12(12 \%)$ \\
\hline Unavailable & $10(10 \%)$ \\
\hline \multicolumn{2}{|c|}{ Estrogen receptor status } \\
\hline Positive & $35(36 \%)$ \\
\hline Negative & $63(64 \%)$ \\
\hline \multicolumn{2}{|c|}{ Progestrone receptor status } \\
\hline Positive & $53(54 \%)$ \\
\hline Negative & $45(16 \%)$ \\
\hline \multicolumn{2}{|c|}{ HER2/neu status(IHC) } \\
\hline Positive & $84(86 \%)$ \\
\hline Negative $^{A}$ & $12(12 \%)$ \\
\hline Unavailable $^{\mathrm{B}}$ & $2(2 \%)$ \\
\hline \multicolumn{2}{|c|}{ TNM stage at diagnosis } \\
\hline I & $9(9 \%)$ \\
\hline II & $35(36 \%)$ \\
\hline III & $34(35 \%)$ \\
\hline IV & $17(17 \%)$ \\
\hline Unavailable & $3(3 \%)$ \\
\hline \multicolumn{2}{|c|}{ Intratumoral TILs } \\
\hline$<10 \%$ & $82(84 \%)$ \\
\hline$\geq 10 \%$ & $16(16 \%)$ \\
\hline
\end{tabular}




\begin{tabular}{ll}
\hline Characteristic & n (\%) \\
\hline Stromal TILs & \\
$<10 \%$ & $41(42 \%)$ \\
$\geq 10 \%$ & $57(58 \%)$ \\
Chemotherapy regimen ${ }^{\mathrm{N}}$ & \\
$\mathrm{A} / \mathrm{T}$ & $46(47 \%)$ \\
$\mathrm{A}+\mathrm{T}$ & $45(46 \%)$ \\
others & $7(7 \%)$ \\
\hline
\end{tabular}

Abbreviation: TILs, tumor-infiltrating lymphocytes; A/T, anthracycline or taxol based regimen; $\mathrm{A}+\mathrm{T}$, anthracycline and taxol based regimen; A: FISH test result was unavailable; B: both IHC and FISH results were unavailable; C: all regimens included anti-Her-2 therapy (trastuzumab);

for intratumoral site, there was no difference between patients with higher and lower FOXP3+ Tregs in OS (Figure 4). A higher number of $\mathrm{CD} 68+\mathrm{M} \varphi$ in intratumoral site tended to result in shortened OS (111.0(91.5-130.5) vs. $147.3(126.0-168.6)$ months; $\mathrm{p}=0.061)$. And similar to intratumoral site, patients had higher stromal CD68+ $\mathrm{M} \varphi$ count had shorter OS (106.6(81.3-132.0) vs. 120.0(106.4-133.5) months; $p=0.014$ ) (Figure 4). For IL-17+ Th17, there was just a trend that in stromal sites higher IL-17+ Th17 count tended to result in shorter OS (97.6(83.9-111.2) vs. 130.3(107.1-153.5) months; $\mathrm{p}=0.524)$. However, in intratumoral site, result of IL-17+ Th17 seemed to conflictive (Figure 4). We also evaluated the effect of FOXP3 expression in tumor cells on overall survival and observed that patients with high level of FOXP3 expression in tumor cells survived a longer time than those with low level of FOXP3 expression. (137.2(117.6-156.8.) vs. 120.7(99.2-142.2) months; $\mathrm{p}=0.043$ ) (Figure 3).

\section{Cox-regression analysis}

The factors found to have an impact on survival (or considered to be effective) including ages at diagnosis, menopausal status, tumor size, nodal status, ER status, PR status, TNM stages, FOXP3+ expression in cancer cells and TILs, and FOXP3+ Tregs, CD68+ M $\varphi$, IL-17+ Th17 in both intratumoral and stromal sites were re-analyzed using Cox regression analyses. In univariate model, nodal status of $\mathrm{N}_{3}$ and $\mathrm{N}_{2}$ [HR: $3.28(1.54-6.95) ; \mathrm{p}=0.002$ ], TNM stages of IV [HR: 4.64 (2.34-9.20); $\mathrm{p}=0.000$ ], stromal TILs $\geq 10 \%$ [HR: 0.52 (0.27-0.99); $\mathrm{p}=0.045]$, high count of stromal FXOP3+ Tregs [HR: 1.95 (1.01-3.75); $\mathrm{p}=0.045$ ], high count of stromal $\mathrm{CD} 68+\mathrm{M} \varphi$ [HR: 2.24 (1.16-4.34); $\mathrm{p}=0.017]$ and high expression of FOXP3 in cancer cells [HR: 0.49 (0.25-0.99); $\mathrm{p}=0.048$ ] had an independent effect on the risk of death (Table 3).

Multivariate analysis was performed using factors which had or tended to have independent effect in univariate analysis and other basically clinical factors of patients. Multivariate analysis showed that age $>50$ years [HR: $0.03(0.00-0.56) ; \mathrm{p}=0.018]$, pre-menopausal [HR: $0.02(0.00-0.29) ; \mathrm{p}=0.005]$, tumor size $>2 \mathrm{~cm}$ [HR: $0.15(0.05-0.47) ; \mathrm{p}=0.001]$, nodal status of $\mathrm{N} 3+\mathrm{N} 2$ [HR: 6.39 (1.90-21.5); $\mathrm{p}=0.003$ ], TNM stages of IV [HR: 5.36 (1.33-21.5); $\mathrm{p}=0.018]$, high count of intratumoral CD68+ $\mathrm{M} \varphi$ [HR: 2.70 (1.00-7.31); $\mathrm{p}=0.050]$ and high expression of FOXP3 in cancer cells [HR: $0.29(0.09-0.91) ; \mathrm{p}=0.034]$ were independent prognostic factors of OS (Table 4).

\section{DISCUSSION}

In this retrospective analysis including 98 breast cancer patients treated with anti-Her-2 therapy, we studied

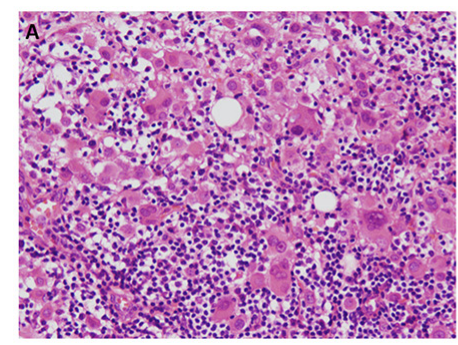

Intratumoral Site

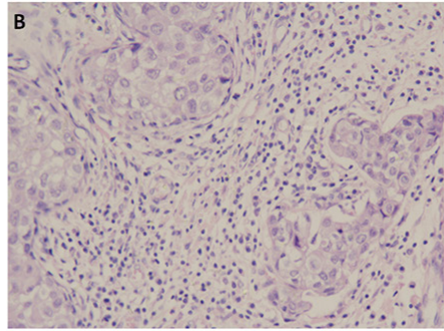

Stromal Site

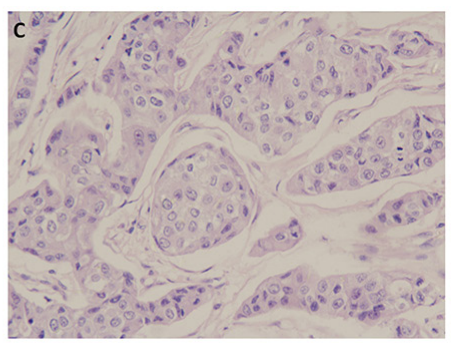

Absence of infiltration

Figure 1: Richness and absence of TILs in intratumoral and stromal sites by HE staining, $1 \times 200$. 

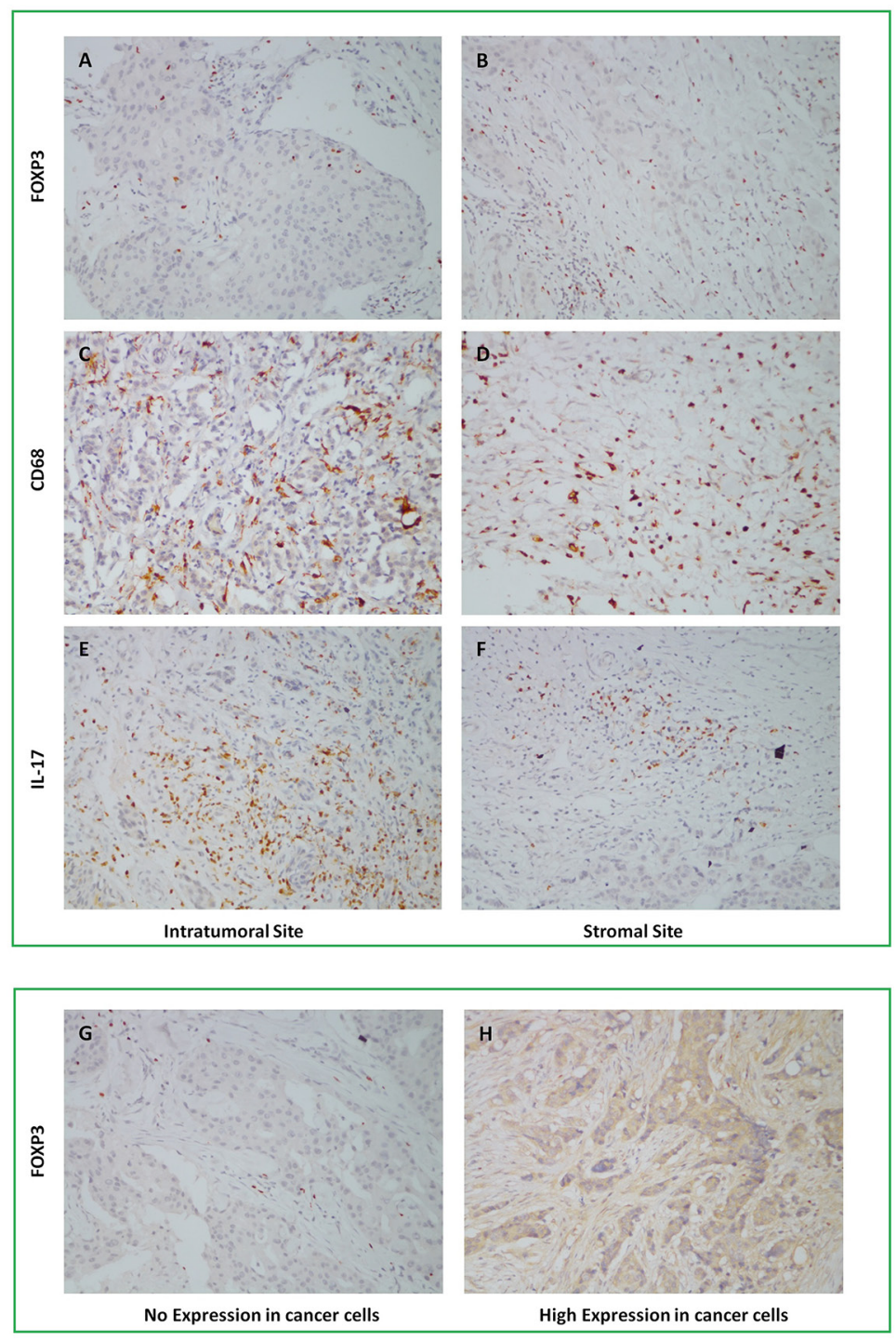

Figure 2: Infiltration of FOXP3+ Tregs, CD68+ M $\varphi$, IL-17+ Th17 in intratumoral and stromal sites, and Foxp3 expression in cancer cells by IHC staining, $1 \times 200$.

potential relationship between TILs infiltration, count of FOXP3 + Tregs, CD68+ M $\varphi$ and IL-17+ Th17 in both intratumoral and stromal site with patients' survival. It suggested that patients with high stromal infiltration of TILs, lower count of FOXP3+ Tregs and CD68+ M $\varphi$ in stromal site, and high expression of FOXP3 in cancer cells had longer survival of OS. In multivariate Cox regression analysis, high count of intratumoral $\mathrm{CD} 68+\mathrm{M} \varphi$ and high expression of FOXP3 in cancer cells were independent prognostic factors for overall survival.

Although the precise mechanism remained unclear, the usual explanation was that different tumor microenvironment may induce $\mathrm{M} \varphi$ having specific functions to facilitate different tumor cell activities [42]. In addition to immune suppression, $\mathrm{M} \varphi$ can release cytokines to regulate tumor growth, angiogenesis, invasion and metastasis. Relationship between $\mathrm{M} \varphi$ and tumor cells was important for vascular invasion of tumor cells within the primary tumor $[26,42]$. Such a mechanism may be used to explain the observation that higher macrophage density was associated with poor prognosis. Studies focused in HCC (hepatocellular carcinoma) found that most of the $\mathrm{M} \varphi$ was unique phenotype with expression of low HLADR (human leukocyte antigen-antigen D related) and high IL-10 in the tumor nests but another different phenotype with expression of moderate HLA-DR and negative IL10 in the peritumoral stromal region [26]. It indicated local microenvironment around tumor nests may promote functional translation of $\mathrm{M} \varphi$ to immunosuppression and tumor-promotion.

Immunosuppression mediated by Tregs was thought to be key reason for tumor immune escape and main obstacle to success of tumor immunotherapy [27]. Soluble cytokines from the tumor microenviroment, especially 
Table 2: Correlation between infiltration of TILs, three different phenotypes of TILs and clinicopathological features of patients

\begin{tabular}{|c|c|c|c|c|c|c|c|c|c|c|c|c|c|c|c|c|c|c|c|c|c|c|c|c|}
\hline \multirow[t]{3}{*}{ Variables } & \multicolumn{6}{|c|}{ TIL } & \multicolumn{6}{|c|}{ FOXP3 } & \multicolumn{6}{|c|}{ CD68 } & \multicolumn{6}{|c|}{ IL-17 } \\
\hline & \multicolumn{3}{|c|}{ IS } & \multicolumn{3}{|c|}{ SS } & \multicolumn{3}{|c|}{ IS } & \multicolumn{3}{|c|}{ SS } & \multicolumn{3}{|c|}{ IS } & \multicolumn{3}{|c|}{ SS } & \multicolumn{3}{|c|}{ IS } & \multicolumn{3}{|c|}{ SS } \\
\hline & $\mathbf{H}$ & $\mathbf{L}$ & $\mathbf{P}$ & $\mathbf{H}$ & $\mathbf{L}$ & $\mathbf{P}$ & $\mathbf{H}$ & $\mathbf{L}$ & $\mathbf{P}$ & $\mathbf{H}$ & $\mathbf{L}$ & $\mathbf{P}$ & $\mathbf{H}$ & $\mathbf{L}$ & $\mathbf{P}$ & $\mathbf{H}$ & $\mathbf{L}$ & $\mathbf{P}$ & $\mathbf{H}$ & $\mathbf{L}$ & $\mathbf{P}$ & $\mathbf{H}$ & $\mathbf{L}$ & $\mathbf{P}$ \\
\hline \multicolumn{25}{|l|}{ Age(years) } \\
\hline$>50$ & 8 & 33 & 0.33 & 24 & 17 & 0.56 & 19 & 22 & 0.34 & 19 & 22 & 0.41 & 18 & 23 & 0.21 & 20 & 21 & 0.57 & 24 & 17 & 0.33 & 23 & 18 & 0.26 \\
\hline$\leq 50$ & 8 & 49 & & 33 & 24 & & 30 & 27 & & 29 & 28 & & 31 & 26 & & 28 & 29 & & 37 & 20 & & 27 & 30 & \\
\hline \multicolumn{25}{|c|}{ Menopausal status } \\
\hline Pre & 9 & 47 & 0.57 & 32 & 24 & 0.49 & 29 & 27 & 0.42 & 28 & 28 & 0.49 & 29 & 27 & 0.42 & 27 & 29 & 0.51 & 35 & 21 & 0.56 & 26 & 30 & 0.20 \\
\hline Post & 7 & 35 & & 25 & 17 & & 20 & 22 & & 20 & 22 & & 20 & 22 & & 21 & 21 & & 26 & 16 & & 24 & 18 & \\
\hline \multicolumn{25}{|l|}{ Tumor Size } \\
\hline$>2 \mathrm{~cm}$ & 9 & 42 & 0.56 & 31 & 20 & 0.54 & 26 & 25 & 0.55 & 22 & 29 & 0.25 & 25 & 26 & 0.45 & 23 & 28 & 0.42 & 35 & 16 & 0.12 & 29 & 22 & 0.11 \\
\hline$\leq 2 \mathrm{~cm}$ & 6 & 26 & & 19 & 13 & & 16 & 16 & & 17 & 15 & & 17 & 15 & & 16 & 16 & & 17 & 15 & & 13 & 19 & \\
\hline UA & 1 & 14 & & 7 & 8 & & 7 & 8 & & 9 & 6 & & 7 & 8 & & 9 & 6 & & 9 & 6 & & 8 & 7 & \\
\hline \multicolumn{25}{|l|}{ Node status } \\
\hline $\mathrm{N}_{3}+\mathrm{N}_{2}$ & 6 & 28 & 0.58 & 22 & 12 & 0.39 & 14 & 20 & 0.14 & 18 & 16 & 0.29 & 15 & 19 & 0.38 & 18 & 16 & 0.23 & 24 & 10 & 0.09 & 20 & 14 & 0.10 \\
\hline $\mathrm{N}_{1}+\mathrm{N}_{0}$ & 10 & 44 & & 32 & 22 & & 30 & 24 & & 24 & 30 & & 27 & 27 & & 23 & 31 & & 29 & 25 & & 23 & 31 & \\
\hline UA & 0 & 10 & & 3 & 7 & & 5 & 5 & & 6 & 4 & & 7 & 3 & & 7 & 3 & & 8 & 2 & & 7 & 3 & \\
\hline \multicolumn{25}{|l|}{ ER status } \\
\hline+ & 3 & 32 & 0.10 & 21 & 14 & 0.48 & 17 & 18 & 0.50 & 16 & 19 & 0.39 & 20 & 15 & 0.20 & 15 & 20 & 0.24 & 18 & 17 & 0.08 & 17 & 18 & 0.44 \\
\hline- & 13 & 50 & & 36 & 27 & & 32 & 31 & & 32 & 31 & & 29 & 34 & & 33 & 30 & & 43 & 20 & & 33 & 30 & \\
\hline \multicolumn{25}{|l|}{ PR status } \\
\hline+ & 8 & 45 & 0.47 & 34 & 19 & 0.14 & 21 & 32 & 0.02 & 22 & 31 & 0.08 & 28 & 25 & 0.34 & 21 & 32 & 0.04 & 31 & 22 & 0.27 & 27 & 26 & 0.57 \\
\hline- & 8 & 37 & & 23 & 22 & & 28 & 17 & & 26 & 19 & & 21 & 24 & & 27 & 18 & & 30 & 15 & & 23 & 22 & \\
\hline \multicolumn{25}{|c|}{ Her-2 status } \\
\hline+ & 15 & 69 & 0.11 & 50 & 34 & 0.20 & 41 & 43 & 0.20 & 41 & 43 & 0.59 & 41 & 43 & 0.38 & 39 & 45 & 0.16 & 55 & 29 & 0.10 & 40 & 44 & 0.18 \\
\hline- & 0 & 12 & & 5 & 7 & & 8 & 4 & & 6 & 6 & & 7 & 5 & & 8 & 4 & & 5 & 7 & & 8 & 4 & \\
\hline UA & 1 & 1 & & 2 & 0 & & 0 & 2 & & 1 & 1 & & 1 & 1 & & 1 & 1 & & 1 & 1 & & 2 & 0 & \\
\hline \multicolumn{25}{|c|}{ TNM-stages } \\
\hline IV & 0 & 17 & 0.03 & 5 & 12 & 0.01 & 9 & 8 & 0.48 & 10 & 7 & 0.31 & 11 & 6 & 0.15 & 11 & 6 & 0.13 & 14 & 3 & 0.05 & 10 & 7 & 0.35 \\
\hline $\mathrm{III}+\mathrm{II}+\mathrm{I}$ & 16 & 62 & & 50 & 28 & & 38 & 40 & & 38 & 40 & & 37 & 41 & & 36 & 42 & & 45 & 33 & & 39 & 39 & \\
\hline UA & 0 & 3 & & 2 & 1 & & 2 & 1 & & 0 & 3 & & 1 & 2 & & 1 & 2 & & 2 & 1 & & 1 & 2 & \\
\hline
\end{tabular}

Abbreviation: TILs, tumor-infiltrating lymphocytes; IS, intratumoral site; SS, stromal site; H, high level; L, low level; P, p-value; UA, unavailable;

cytokines secreted by tumor cells and APCs (antigen presenting cells), can induce aggregation, proliferation and migration of Tregs [27]. Previous studies reported that as component of peripheral blood circulation and TILs, increased Tregs can weaken cell-mediated immunity therefore promoted disease progression in ovarian cancer or esophageal and gastric cancer [43-45]. Studies showed that elimination of Tregs in melanoma mouse model can increase the effectiveness of immunotherapy and disappearance rate of tumor lesions [46, 47]. Moreover, elimination of CD4+\&CD25+ Tregs in advanced cancer patients promoted efficacy of T cells and NK cells $[48,49]$. These evidences suggested that Tregs can destruct cell- mediated immune response to tumor. Zheng et al found increasement of intratumoral FOXP3+ Tregs was linked to shorter OS and DFS and was independent prognostic factor in HCC patients [50]. Bohling and Allison found density of intratumoral FOXP3+ Tregs was significantly associated with high histological grade, larger size and ER negative status in breast cancer [51]. This also supported our study that higher infiltration of FOXP3 + Tregs in stromal site was associated with poor prognosis in breast cancer patients, although no significant difference was found when it comes to intratumoral site.

Studies also reported that many tumor cell lines including lung cancer, colon cancer, breast cancer, 

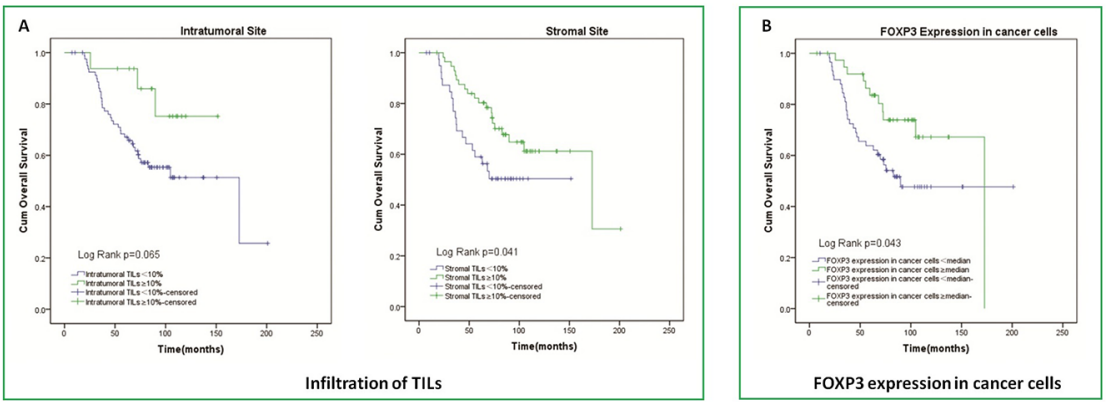

Figure 3: Kaplan-Meier curves of overall survival according to TILs infiltration in intratumoral and stromal sites and FOXP3 expression in cancer cells.
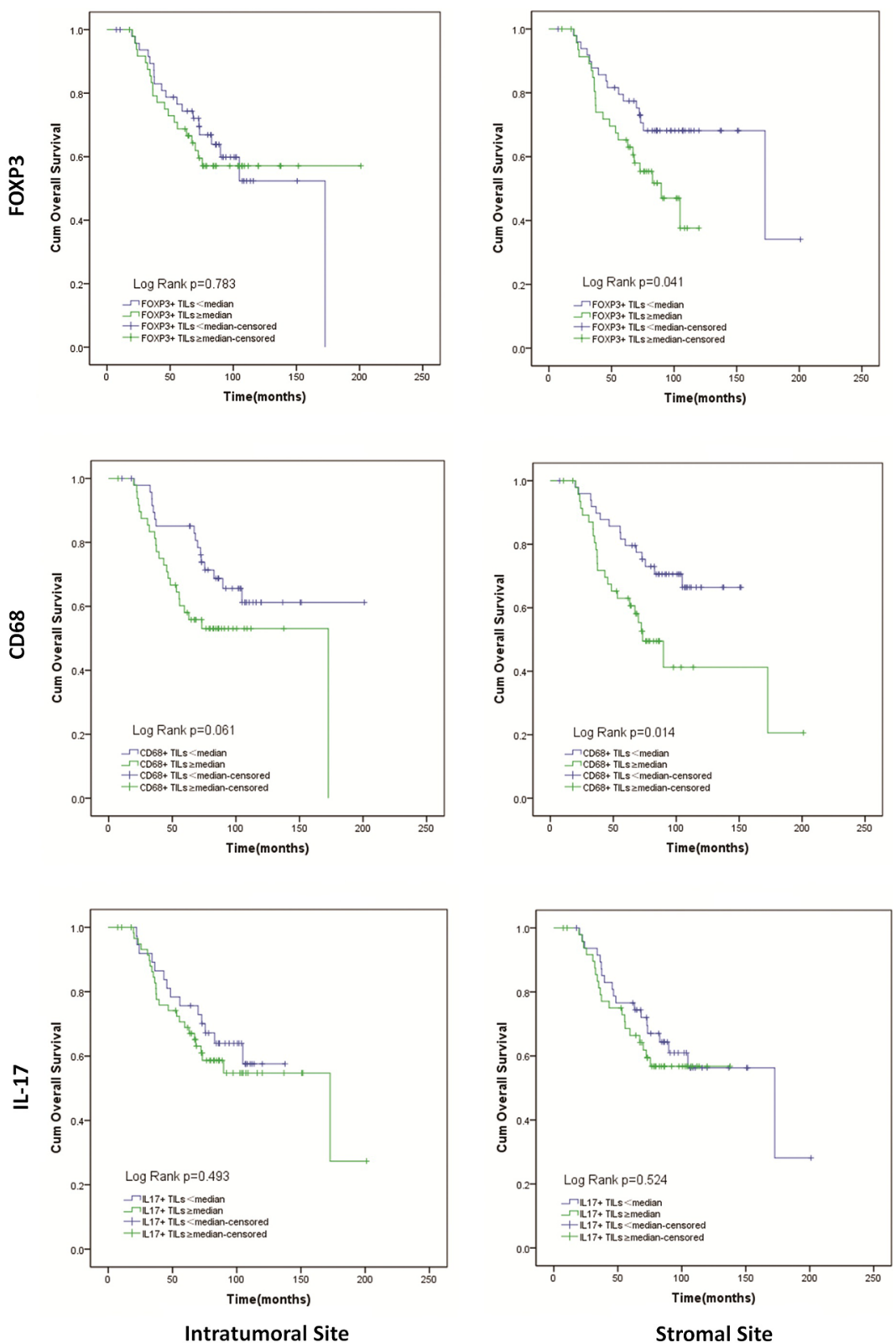

Figure 4: Kaplan-Meier curves of overall survival according to infiltration of FOXP3+ Tregs, CD68+ M $\varphi$, IL-17+ Th17 in intratumoral and stromal sites. 
Table 3: Univariate analysis of factors associated with overall survival

\begin{tabular}{lccc}
\hline Variable & HR & $\mathbf{9 5 \%}$ CI & P-value \\
\hline Age at diagnosis $(\mathrm{y}>50 / \mathrm{y} \leq 50)$ & 1.49 & $0.79-2.82$ & $\mathbf{0 . 2 1 8}$ \\
Menopausal status $($ Pre/Post) & 0.66 & $0.35-1.23$ & $\mathbf{0 . 1 9 2}$ \\
Tumor size $(>2 \mathrm{~cm} / \leq 2 \mathrm{~cm})$ & 0.55 & $0.27-1.14$ & $\mathbf{0 . 1 0 9}$ \\
Nodal status $\left(\mathrm{N}_{3}+\mathrm{N}_{2} / \mathrm{N}_{1}+\mathrm{N}_{0}\right)$ & 3.28 & $1.54-6.95$ & $\mathbf{0 . 0 0 2}$ \\
ER status $(+/-)$ & 0.67 & $0.34-1.34$ & $\mathbf{0 . 2 6 0}$ \\
PR status $(+/-)$ & 0.64 & $0.34-1.20$ & $\mathbf{0 . 1 6 3}$ \\
TNM stages (IV/III+II+I) & 4.64 & $2.34-9.20$ & $\mathbf{0 . 0 0 0}$ \\
Intratumoral TILs $(\geq 10 \% /<10 \%)$ & 0.35 & $0.11-1.13$ & $\mathbf{0 . 0 7 8}$ \\
Stromal TILs $(\geq 10 \% /<10 \%)$ & 0.52 & $0.27-0.99$ & $\mathbf{0 . 0 4 5}$ \\
Intratumoral FXOP3+ Tregs (high/low) & 1.09 & $0.58-2.05$ & $\mathbf{0 . 7 8 3}$ \\
Stromal FXOP3+ Tregs (high/low) & 1.95 & $1.01-3.75$ & $\mathbf{0 . 0 4 5}$ \\
Intratumoral CD68+ M $\varphi($ high/low) & 1.83 & $0.96-3.49$ & $\mathbf{0 . 0 6 5}$ \\
Stromal CD68+ M $\varphi($ high/low) & 2.24 & $1.16-4.34$ & $\mathbf{0 . 0 1 7}$ \\
Intratumoral IL17+ Th17 (high/low) & 1.26 & $0.65-2.44$ & $\mathbf{0 . 4 9 4}$ \\
Stromal IL17+ Th17 (high/low) & 1.23 & $0.65-2.33$ & $\mathbf{0 . 5 2 5}$ \\
FOXP3+ cancer cells (high/low) & 0.49 & $0.25-0.99$ & $\mathbf{0 . 0 4 8}$ \\
\hline
\end{tabular}

Abbreviation: HR, hazard ratio; CI, confidence interval; ER, estrogen receptor; PR, progestrone receptor; TILs, tumorinfiltrating lymphocytes; Tregs, regulatory T cells; M $\varphi$, macrophage; Th17, T helper cell 17;

melanoma, acute T-cell leukemia cell lines can express FOXP3 protein [52]. Coincidentally, in this study, in addition to FOXP3+ Tregs we also found that there were tissue samples expressing FOXP3 protein in tumor cells. In 103 breast cancer tissue samples stained with FOXP3 antibody by IHC, Ladoire et al found 57\% of tumors expressing different levels of FOXP3 protein and as independent prognostic factor, high level of FOXP3 protein expression was associated with prolonged DFS and OS [53]. Zuo et al also compared expression of FOXP3 and Her-2 protein by IHC in breast cancer tissue and found downregulation of FOXP3 protein was significantly with overexpression of Her-2 protein [54]. They also confirmed that FOXP3 was X-linked and was important suppressor gene of both breast cancer and Her2/ErbB2 proto-oncogene [54]. Other finds were including but not only that $80 \%$ of the normal epithelial cells in breast tissue expressed FOXP3 and only $20 \%$ of breast cancer tissue expressed it by IHC [54]. Thus, it can be explained that in our study high expression of FOXP3 in cancer cells was associated with prolonged OS.

Studies reported TNF- $\beta$ (tumor necrosis factor $\beta$ ) played a key role in determining the differentiation of CD4+ lymphocytes to be Tregs or Th17 [55, 56]. Th17 were defined as one of the subtype of CD4+ lymphocytes characterized in that Th17 can produce IL-6, IL-17 and TNF- $\alpha$, etc. Differentiation of Th17 was induced by IL-23 which was also inducer of autoimmune encephalitis [57, 58]. Balance between Tregs and Th17 may affect the antitumor immune response and more Tregs tended to result in tumor's immune escape. Recently studies suggested that IL-17 and its producing cells Th17 were disadvantageous factors in breast cancer by changing the behavior of tumor cells, eliciting tumorigenic neutrophils recruitment [59], promoting chemoresistance, proliferation of tumor cells [60], tumor angiogenesis [61] and metastasis [62]. Moreover, by flow cytometry, Horlock et al observed that both Th17 and FOXP3 + Tregs increased in peripheral blood of breast cancer patients and with the treatment of trastuzumab, Th17 increased but FOXP3+ Tregs decreased which led to changes of Th17/Tregs ratio [35]. Such dynamic balance between Th17 and Tregs can reflect even predict the efficacy of trastuzumab [35]. However, we did not find obvious relationship between Th17 and prognosis or relationship between Th17 and anti-Her-2 therapy probably due to relatively less expression of IL-17 in this study.

Furthermore, study showed that the delayed use of trastuzumab has no negative effect on the OS of Her-2 positive advanced breast cancer patients and there is a trend of improved OS over the patients with repeated use of trastuzumab [63]. This evidence further supported that anti-Her2 therapy is closely associated with immune system, because it can't be fully explained that trastuzumab still had effect after tumor progression just 
Table 4: Multivariate analysis of factors associated with overall survival

\begin{tabular}{llcc}
\hline Variable & HR & $\mathbf{9 5 \%}$ CI & P-value \\
\hline Age at diagnosis $(\mathrm{y}>50 / \mathrm{y} \leq 50)$ & 0.03 & $0.00-0.56$ & $\mathbf{0 . 0 1 8}$ \\
Menopausal status $($ Pre/Post) & 0.02 & $0.00-0.29$ & $\mathbf{0 . 0 0 5}$ \\
Tumor size $(>2 \mathrm{~cm} / \leq 2 \mathrm{~cm})$ & 0.15 & $0.05-0.47$ & $\mathbf{0 . 0 0 1}$ \\
Nodal status $\left(\mathrm{N}_{3}+\mathrm{N}_{2} / \mathrm{N}_{1}+\mathrm{N}_{0}\right)$ & 6.39 & $1.90-21.5$ & $\mathbf{0 . 0 0 3}$ \\
ER status $(+/-)$ & 0.65 & $0.24-1.75$ & $\mathbf{0 . 3 9 0}$ \\
PR status ( $/-)$ & 1.50 & $0.53-4.21$ & $\mathbf{0 . 4 4 2}$ \\
TNM stages $(\mathrm{IV} / \mathrm{III}+\mathrm{II}+\mathrm{I})$ & 5.36 & $1.33-21.5$ & $\mathbf{0 . 0 1 8}$ \\
Intratumoral TILs $(\geq 10 \% /<10 \%)$ & 0.32 & $0.06-1.56$ & $\mathbf{0 . 1 5 7}$ \\
Stromal TILs $(\geq 10 \% /<10 \%)$ & 1.12 & $0.41-3.08$ & $\mathbf{0 . 8 3 1}$ \\
Stromal FXOP3+ Tregs $($ high/low) & 1.34 & $0.53-3.38$ & $\mathbf{0 . 5 3 4}$ \\
Intratumoral CD68+ M $\varphi$ (high/low) & 2.70 & $1.00-7.31$ & $\mathbf{0 . 0 5 0}$ \\
Stromal CD68+ M $\varphi$ (high/low) & 1.85 & $0.72-4.73$ & $\mathbf{0 . 2 0 0}$ \\
FOXP3+ cancer cells (high/low) & 0.29 & $0.09-0.91$ & $\mathbf{0 . 0 3 4}$ \\
\hline
\end{tabular}

Abbreviation: HR, hazard ratio; CI, confidence interval; ER, estrogen receptor; PR, progestrone receptor; TILs, tumorinfiltrating lymphocytes; Tregs, regulatory $\mathrm{T}$ cells; $\mathrm{M} \varphi$, macrophage;

by blocking Her-2 signaling pathway unless it promote the anti-tumor immune response by long-term or repeated use of trastuzumab. It suggested on the other hand that infiltration of TILs and its different phenotype in tumor microenvironment affect the efficacy of anti-Her2 therapy. In addition, at the genetic level related genes associated with TILs, FOXP3, CD68 and IL-17 were also reported. By comparing the gene expression pattern of TILs with reported data and UniGene, $\mathrm{Li}$, B. et al demonstrated the parallel gene expression of TILs had an important role in T-cell activity, infiltrating of TILs within tumor tissue and photokilling effect against tumor cells of TILs [64]. There was another first-in-man trial showing that administration of TILs with transduction of an inducible IL12 gene can mediate tumor responses [65]. Evidences indicated CD8+ TILs can be activated by IL-2 secreted by TILs and IL-2 gene expression may be an available prognostic factor in HCC [66]. It seemed that IL-17 gene maybe had a similar function and mechanism. However, the difference was IL17 gene polymorphism. E. LBassuoni MA et al showed the GG, GG+GA genotypes of IL-17A gene promoted the development of HCC through increased IL17 and IgE [67]. Higher immune gene expression of IL-17 was also been proven to be a determinant in mismatch repair proficient colorectal cancer, and so was FOXP3 [68]. In studies of nearly two years, genome-wide analysis of Foxp3 expression in tongue squamous cell carcinoma cells revealed that Foxp3 gene had more significant biological effects in tumor cells compared with that in FOXP3 + Tregs and consequently demonstrated diverse genes that FOXP3 gene directly or indirectly targeted in tumor cells [69]. As a suppressor gene in breast cancer cells, there was also research showing that interaction of Runx1 and FOXP3 genes can affected gene expression profile of mammary epithelial cell gene and finally Runx 1 cause breast cancer progression on FOXP3 availability [70]. For CD68, Tymoszuk, P. et al showed that the higher expression of related gene STAT1 was related to increased expression of tumor-associated macrophages gene such CD68 and led to poor prognosis [71].

In conclusion, the retrospective study including 98 breast cancer patients treated with anti-Her-2 therapy revealed that tumor TILs as well as its FOXP3+, CD68+ phenotypes in stromal site, and expression of FOXP3 in cancer cells were significantly associated with OS. Patients with high stromal infiltration of TILs, lower count of FOXP3+ Tregs and $\mathrm{CD} 68+\mathrm{M} \varphi$ in stromal site, and high expression of FOXP3 in cancer cells had longer OS. And high count of intratumoral $\mathrm{CD} 68+\mathrm{M} \varphi$ and high expression of FOXP3 in cancer cells were independent prognostic factors for overall survival. It suggested that TILs and its specific subtype can be used as important pathological factor predicting prognosis of breast cancer patients treated with anti-Her-2 therapy. Further analysis with a larger sample or a prospective study was needed to validate the conclusion.

\section{MATERIALS AND METHODS}

\section{Ethical statement}

The study was approved by the Institutional Review Board of Sun Yat-Sen University Cancer Center (Guangzhou, China). 


\section{Patients and tissue samples}

Between 1999 and 2010, 98 female patients who were diagnosed with primary breast cancer and received follow-up treatment at Sun-Yat-Sen University Cancer Center were included in the study. Tissue samples were collected post-operation but before chemotherapy and all the patients had provided written informed consent before collection. Clinicopathological information was shown in Table 1 including age at diagnosis, menopausal status, tumor size, nodal status, hormone receptor status, Her2 status, TNM stages, chemotherapy regimens, etc. All patients received anti-Her-2 therapy.

\section{HE (hematoxylin and eosin) staining and evaluation of TILs}

Full-face hematoxylin-and-eosin-stained sections were histopathologically evaluated for TILs. Intratumoral lymphocytes were defined as intraepithelial mononuclear cells within tumor cell nests or in direct contact with tumor cells and were reported as the percentage of the tumor epithelial nests that contained infiltrating lymphocytes. Stromal lymphocytes were defined as the percentage of tumor stroma area that contained a lymphocytic infiltrate without direct contact to tumor cells [6]. Two reviewers who were blind to clinical background performed histopathologic evaluation independently. For TILs, percent of lymphocytic infiltration was used to distinguish high or low level of TILs by above or below $10 \%$.

\section{IHC staining and quantification of FOXP3+ Tregs, CD68+ M $\varphi$ and IL-17+ Th17}

Formalin-fixed, paraffin-embedded tissue were sectioned into thick slices $(5 \mu \mathrm{m})$ and then mounted on poly-L-lysine-coated adhesive slides. After drying at $60^{\circ} \mathrm{C}$ for 2 hours, tissue sections were dewaxed in xylene, then rehydrated through a graded ethanol series followed by $0.3 \%$ hydrogen peroxide in methanol for $10 \mathrm{~min}$ to inhibit endogenous peroxidase activity. After standard microwave heat epitope retrieval for 30 mins in citrate buffer solution, $\mathrm{pH}$ 6.0, samples were incubated with antibodies to FOXP3(1:100 dilution; Abcam, UK), CD68(1:800 dilution; R\&D, USA), IL-17(1:150 dilution; ZSGB-Bio, China) for 12-14 hours at $4^{\circ} \mathrm{C}$. Sections were subsequently incubated with an appropriate reagent from the EnVision ${ }^{\mathrm{TM}}$ Detection DAB kit (Dako) and counterstained with Harris hematoxylin.

Two reviewers who were blind to clinical background performed immunohistochemical evaluation independently. And FOXP3+ Tregs, CD68+ M $\varphi$ and IL-17+ Th17 in intratumoral and stromal site were firstly counted in 3 representative high-power fields respectively (HPF; x20 objective and $\mathrm{x} 10$ eyepiece), then the calculated average value of three counts>median was defined as patients with high numbers of FOXP3+ Tregs, CD68+ M $\varphi$ and IL-17+
Th17 in surgical specimens before chemotherpay. Definition of IHC positive cells of each marker in intratumoral and stromal sites was just as same as TILs in intratumoral and stromal sites. In some specimens, FOXP3 was also expressed in cancer cells and reported as the percentage of the tumor cells expressed it. The percent value>median was defined as patients with high FOXP3 expression in cancer cells.

\section{Statistical analyses}

The association between count of FOXP3+ Tregs, CD68+ M $\varphi$, IL-17+ Th17 and infiltration level of TILs with clinicopathological/biological features was examined using the chi-square test. Correlations between FOXP3+ Tregs, CD68+ M $\varphi$, IL-17+ Th17 and infiltration level of TILs with OS were analyzed by Kaplan-Meier survival curves using the log-rank tests. Associations between count of FOXP3+ Tregs, CD68+ M $\varphi$, IL-17+ Th17 and infiltration level of TILs and prognosis were assessed using the Cox proportional hazard model. All data were processed by SPSS 19.0 and $\mathrm{P}<0.05$ was considered statistically significant.

\section{CONFLICTS OF INTEREST}

The authors declared that they have no competing interests.

\section{GRANT SUPPORT}

This study received funding support from Science and technology foundation of Guangdong province (2013B021800062 and 2012B06170008), the international collaboration foundation of science and Technology Planning Project of Guangdong Province of China (2016A050502015) and Health \& Medical Collaborative Innovation Project of Guangzhou City, China (No. 201400000001).

\section{REFERENCES}

1. Torre LA, Bray F, Siegel RL, Ferlay J, Lortet-Tieulent J, Jemal A. Global cancer statistics, 2012. CA Cancer J Clin. 2015; 65: 87-108. doi: 10.3322/caac.21262.

2. Slamon DJ, Clark GM, Wong SG, Levin WJ, Ullrich A, McGuire WL. Human breast cancer: correlation of relapse and survival with amplification of the HER-2/neu oncogene. Science. 1987; 235: 177-82.

3. Cobleigh MA, Vogel CL, Tripathy D, Robert NJ, Scholl S, Fehrenbacher L, Wolter JM, Paton V, Shak S, Lieberman G, Slamon DJ. Multinational study of the efficacy and safety of humanized anti-HER2 monoclonal antibody in women who have HER2-overexpressing metastatic breast cancer that has progressed after chemotherapy for metastatic disease. J Clin Oncol. 1999; 17: 2639-48.

4. Ladjemi MZ, Jacot W, Chardes T, Pelegrin A, NavarroTeulon I. Anti-HER2 vaccines: new prospects for breast 
cancer therapy. Cancer Immunol Immunother. 2010; 59: 1295-312. doi: 10.1007/s00262-010-0869-2.

5. Disis M L SJ, Wallace D, et al. Cellular immune parameters associated with improved long-term survival in advanced stage breast cancer patients after active immunization with a HER2-specific vaccine. ASCO. 2008; 3015.

6. Denkert C, Loibl S, Noske A, Roller M, Muller BM, Komor M, Budczies J, Darb-Esfahani S, Kronenwett R, Hanusch C, von Torne C, Weichert W, Engels K, et al. Tumor-associated lymphocytes as an independent predictor of response to neoadjuvant chemotherapy in breast cancer. J Clin Oncol. 2010; 28: 105-13. doi: 10.1200/jco.2009.23.7370.

7. de Visser KE, Eichten A, Coussens LM. Paradoxical roles of the immune system during cancer development. Nat Rev Cancer. 2006; 6: 24-37. doi: 10.1038/nrc1782.

8. Park S, Jiang Z, Mortenson ED, Deng L, Radkevich-Brown O, Yang X, Sattar H, Wang Y, Brown NK, Greene M, Liu Y, Tang J, Wang S, et al. The therapeutic effect of anti-HER2/ neu antibody depends on both innate and adaptive immunity. Cancer Cell. 2010; 18: 160-70. doi: 10.1016/j.ccr.2010.06.014.

9. Ladoire S, Arnould L, Mignot G, Apetoh L, Rebe C, Martin F, Fumoleau P, Coudert B, Ghiringhelli F. T-bet expression in intratumoral lymphoid structures after neoadjuvant trastuzumab plus docetaxel for HER2-overexpressing breast carcinoma predicts survival. Br J Cancer. 2011; 105: 36671. doi: 10.1038/bjc.2011.261.

10. Ignatiadis M, Singhal SK, Desmedt C, Haibe-Kains B, Criscitiello C, Andre F, Loi S, Piccart M, Michiels S, Sotiriou C. Gene modules and response to neoadjuvant chemotherapy in breast cancer subtypes: a pooled analysis. J Clin Oncol. 2012; 30: 1996-2004. doi: 10.1200/jco.2011.39.5624.

11. Stagg J, Loi S, Divisekera U, Ngiow SF, Duret H, Yagita H, Teng MW, Smyth MJ. Anti-ErbB-2 mAb therapy requires type I and II interferons and synergizes with anti-PD-1 or anti-CD137 mAb therapy. Proc Natl Acad Sci U S A. 2011; 108: 7142-7. doi: 10.1073/pnas.1016569108.

12. Clynes RA, Towers TL, Presta LG, Ravetch JV. Inhibitory Fc receptors modulate in vivo cytotoxicity against tumor targets. Nat Med. 2000; 6: 443-6. doi: 10.1038/74704.

13. West NR, Milne K, Truong PT, Macpherson N, Nelson $\mathrm{BH}$, Watson PH. Tumor-infiltrating lymphocytes predict response to anthracycline-based chemotherapy in estrogen receptor-negative breast cancer. Breast Cancer Res. 2011; 13: R126. doi: 10.1186/bcr3072.

14. Ono M, Tsuda H, Shimizu C, Yamamoto S, Shibata T, Yamamoto H, Hirata T, Yonemori K, Ando M, Tamura K, Katsumata N, Kinoshita T, Takiguchi Y, et al. Tumorinfiltrating lymphocytes are correlated with response to neoadjuvant chemotherapy in triple-negative breast cancer. Breast Cancer Res Treat. 2012; 132: 793-805. doi: 10.1007/ s10549-011-1554-7.

15. Loubiere LS, Lambert NC, Flinn LJ, Erickson TD, Yan Z, Guthrie KA, Vickers KT, Nelson JL. Maternal microchimerism in healthy adults in lymphocytes, monocyte/macrophages and NK cells. Lab Invest. 2006; 86: 1185-92. doi: 10.1038/labinvest.3700471.

16. Lee HJ, Seo JY, Ahn JH, Ahn SH, Gong G. Tumorassociated lymphocytes predict response to neoadjuvant chemotherapy in breast cancer patients. J Breast Cancer. 2013; 16: 32-9. doi: 10.4048/jbc.2013.16.1.32.

17. Ko JJ, Choueiri TK, Rini BI, Lee JL, Kroeger N, Srinivas S, Harshman LC, Knox JJ, Bjarnason GA, MacKenzie MJ, Wood L, Vaishampayan UN, Agarwal N, et al. First-, second-, third-line therapy for mRCC: benchmarks for trial design from the IMDC. Br J Cancer. 2014; 110: 1917-22. doi: 10.1038/bjc.2014.25.

18. Teixeira L, Rothé F, Ignatiadis M, Sotiriou C. Breast Cancer Immunology. Oncology Times. 2016; 38: 18-9. doi: 10.1097/01.COT.0000483221.52404.e3.

19. Heuff G, Oldenburg HS, Boutkan H, Visser JJ, Beelen RH, Van Rooijen N, Dijkstra CD, Meyer S. Enhanced tumour growth in the rat liver after selective elimination of Kupffer cells. Cancer Immunol Immunother. 1993; 37: 125-30.

20. Bayon LG, Izquierdo MA, Sirovich I, van Rooijen N, Beelen $\mathrm{RH}$, Meijer S. Role of Kupffer cells in arresting circulating tumor cells and controlling metastatic growth in the liver. Hepatology. 1996; 23: 1224-31. doi: 10.1002/hep.510230542.

21. Bowles JA, Weiner GJ. CD16 polymorphisms and NK activation induced by monoclonal antibody-coated target cells. J Immunol Methods. 2005; 304: 88-99. doi: 10.1016/j. jim.2005.06.018.

22. Mantovani A, Sozzani S, Locati M, Allavena P, Sica A. Macrophage polarization: tumor-associated macrophages as a paradigm for polarized M2 mononuclear phagocytes. Trends Immunol. 2002; 23: 549-55.

23. Kryczek I, Zou L, Rodriguez P, Zhu G, Wei S, Mottram P, Brumlik M, Cheng P, Curiel T, Myers L, Lackner A, Alvarez X, Ochoa A, et al. B7-H4 expression identifies a novel suppressive macrophage population in human ovarian carcinoma. J Exp Med. 2006; 203: 871-81. doi: 10.1084/ jem.20050930.

24. Taylor C, Hershman D, Shah N, Suciu-Foca N, Petrylak DP, Taub R, Vahdat L, Cheng B, Pegram M, Knutson KL, Clynes R. Augmented HER-2 specific immunity during treatment with trastuzumab and chemotherapy. Clin Cancer Res. 2007; 13: 5133-43. doi: 10.1158/1078-0432.ccr-07-0507.

25. Fontenot JD, Gavin MA, Rudensky AY. Foxp3 programs the development and function of CD4+CD25+ regulatory T cells. Nat Immunol. 2003; 4: 330-6. doi: 10.1038/ni904.

26. Kuang DM, Wu Y, Chen N, Cheng J, Zhuang SM, Zheng L. Tumor-derived hyaluronan induces formation of immunosuppressive macrophages through transient early activation of monocytes. Blood. 2007; 110: 587-95. doi: 10.1182/blood-2007-01-068031.

27. Zou W. Regulatory $\mathrm{T}$ cells, tumour immunity and immunotherapy. Nat Rev Immunol. 2006; 6: 295-307. doi: 10.1038/nri1806. 
28. Li L, Li SP, Min J, Zheng L. Hepatoma cells inhibit the differentiation and maturation of dendritic cells and increase the production of regulatory T cells. Immunol Lett. 2007; 114: 38-45. doi: 10.1016/j.imlet.2007.09.003.

29. Pollard JW. Tumour-educated macrophages promote tumour progression and metastasis. Nat Rev Cancer. 2004; 4: 71-8. doi: $10.1038 / \mathrm{nrc} 1256$.

30. Wolf AM, Wolf D, Steurer M, Gastl G, Gunsilius E, Grubeck-Loebenstein B. Increase of regulatory $T$ cells in the peripheral blood of cancer patients. Clin Cancer Res. 2003; 9: 606-12.

31. Gajewski TF. The expanding universe of regulatory $\mathrm{T}$ cell subsets in cancer. Immunity. 2007; 27: 185-7. doi: 10.1016/j.immuni.2007.08.001.

32. Wang HY, Wang RF. Regulatory $T$ cells and cancer. Curr Opin Immunol. 2007; 19: 217-23. doi: 10.1016/j. coi.2007.02.004.

33. Dong C. TH17 cells in development: an updated view of their molecular identity and genetic programming. Nat Rev Immunol. 2008; 8: 337-48. doi: 10.1038/nri2295.

34. Stockinger B, Veldhoen M. Differentiation and function of Th17 T cells. Curr Opin Immunol. 2007; 19: 281-6. doi: 10.1016/j.coi.2007.04.005.

35. Horlock C, Stott B, Dyson PJ, Morishita M, Coombes RC, Savage P, Stebbing J. The effects of trastuzumab on the CD4+CD25+FoxP3+ and CD4+IL17A+ T-cell axis in patients with breast cancer. Br J Cancer. 2009; 100: 1061-7. doi: 10.1038/sj.bjc.6604963.

36. Perez EA, Reinholz MM, Hillman DW, Tenner KS, Schroeder MJ, Davidson NE, Martino S, Sledge GW, Harris LN, Gralow JR, Dueck AC, Ketterling RP, Ingle JN, et al. HER 2 and chromosome 17 effect on patient outcome in the N9831 adjuvant trastuzumab trial. J Clin Oncol. 2010; 28: 4307-15. doi: 10.1200/jco.2009.26.2154.

37. de Alava E, Ocana A, Abad M, Montero JC, EsparisOgando A, Rodriguez CA, Otero AP, Hernandez T, Cruz JJ, Pandiella A. Neuregulin expression modulates clinical response to trastuzumab in patients with metastatic breast cancer. J Clin Oncol. 2007; 25: 2656-63. doi: 10.1200/ jco.2006.08.6850.

38. Huang X, Gao L, Wang S, McManaman JL, Thor AD, Yang X, Esteva FJ, Liu B. Heterotrimerization of the growth factor receptors erbB2, erbB3, and insulin-like growth factor-i receptor in breast cancer cells resistant to herceptin. Cancer Res. 2010; 70: 1204-14. doi: 10.1158/0008-5472.can-09-3321.

39. Ross JS, Slodkowska EA, Symmans WF, Pusztai L, Ravdin PM, Hortobagyi GN. The HER-2 receptor and breast cancer: ten years of targeted anti-HER-2 therapy and personalized medicine. Oncologist. 2009; 14: 320-68. doi: 10.1634/theoncologist.2008-0230.

40. DeNardo DG, Brennan DJ, Rexhepaj E, Ruffell B, Shiao SL, Madden SF, Gallagher WM, Wadhwani N, Keil SD, Junaid SA, Rugo HS, Hwang ES, Jirstrom K, et al. Leukocyte complexity predicts breast cancer survival and functionally regulates response to chemotherapy. Cancer Discov. 2011; 1: 54-67. doi: 10.1158/2159-8274.cd-10-0028.

41. Lutsiak ME, Semnani RT, De Pascalis R, Kashmiri SV, Schlom J, Sabzevari H. Inhibition of CD4 $(+) 25+\mathrm{T}$ regulatory cell function implicated in enhanced immune response by low-dose cyclophosphamide. Blood. 2005; 105: 2862-8. doi: 10.1182/blood-2004-06-2410.

42. Lewis CE, Pollard JW. Distinct role of macrophages in different tumor microenvironments. Cancer Res. 2006; 66: 605-12. doi: 10.1158/0008-5472.can-05-4005.

43. Woo EY, Chu CS, Goletz TJ, Schlienger K, Yeh H, Coukos G, Rubin SC, Kaiser LR, June CH. Regulatory CD4(+) $\mathrm{CD} 25(+) \mathrm{T}$ cells in tumors from patients with early-stage non-small cell lung cancer and late-stage ovarian cancer. Cancer Res. 2001; 61: 4766-72.

44. Curiel TJ, Coukos G, Zou L, Alvarez X, Cheng P, Mottram P, Evdemon-Hogan M, Conejo-Garcia JR, Zhang L, Burow M, Zhu Y, Wei S, Kryczek I, et al. Specific recruitment of regulatory $\mathrm{T}$ cells in ovarian carcinoma fosters immune privilege and predicts reduced survival. Nat Med. 2004; 10 : 942-9. doi: 10.1038/nm1093.

45. Kono K, Kawaida H, Takahashi A, Sugai H, Mimura K, Miyagawa N, Omata H, Fujii H. CD4(+)CD25high regulatory $\mathrm{T}$ cells increase with tumor stage in patients with gastric and esophageal cancers. Cancer Immunol Immunother. 2006; 55 : 1064-71. doi: 10.1007/s00262-005-0092-8.

46. Shimizu J, Yamazaki S, Sakaguchi S. Induction of tumor immunity by removing CD25+CD4+ T cells: a common basis between tumor immunity and autoimmunity. J Immunol. 1999; 163: 5211-8.

47. Steitz J, Bruck J, Lenz J, Knop J, Tuting T. Depletion of $\mathrm{CD} 25(+) \mathrm{CD} 4(+) \mathrm{T}$ cells and treatment with tyrosinaserelated protein 2-transduced dendritic cells enhance the interferon alpha-induced, CD8(+) T-cell-dependent immune defense of B16 melanoma. Cancer Res. 2001; 61: 8643-6.

48. Ghiringhelli F, Menard C, Puig PE, Ladoire S, Roux S, Martin F, Solary E, Le Cesne A, Zitvogel L, Chauffert B. Metronomic cyclophosphamide regimen selectively depletes CD4+CD25+ regulatory $\mathrm{T}$ cells and restores $\mathrm{T}$ and $\mathrm{NK}$ effector functions in end stage cancer patients. Cancer Immunol Immunother. 2007; 56: 641-8. doi: 10.1007/s00262-006-0225-8.

49. Mahnke K, Schonfeld K, Fondel S, Ring S, Karakhanova S, Wiedemeyer K, Bedke T, Johnson TS, Storn V, Schallenberg $\mathrm{S}$, Enk AH. Depletion of CD4+CD25+ human regulatory T cells in vivo: kinetics of Treg depletion and alterations in immune functions in vivo and in vitro. Int J Cancer. 2007; 120: 2723-33. doi: 10.1002/ijc.22617.

50. Zhou J, Ding T, Pan W, Zhu LY, Li L, Zheng L. Increased intratumoral regulatory $\mathrm{T}$ cells are related to intratumoral macrophages and poor prognosis in hepatocellular carcinoma patients. Int J Cancer. 2009; 125: 1640-8. doi: 10.1002/ijc.24556.

51. Bohling SD, Allison KH. Immunosuppressive regulatory $\mathrm{T}$ cells are associated with aggressive breast cancer 
phenotypes: a potential therapeutic target. Mod Pathol. 2008; 21: 1527-32. doi: 10.1038/modpathol.2008.160.

52. Karanikas V, Speletas M, Zamanakou M, Kalala F, Loules G, Kerenidi T, Barda AK, Gourgoulianis KI, Germenis AE. Foxp3 expression in human cancer cells. J Transl Med. 2008; 6: 19. doi: 10.1186/1479-5876-6-19.

53. Ladoire S, Arnould L, Mignot G, Coudert B, Rebe C, Chalmin F, Vincent J, Bruchard M, Chauffert B, Martin F, Fumoleau P, Ghiringhelli F. Presence of Foxp3 expression in tumor cells predicts better survival in HER2-overexpressing breast cancer patients treated with neoadjuvant chemotherapy. Breast Cancer Res Treat. 2011; 125: 65-72. doi: 10.1007/s10549-010-0831-1.

54. Zuo T, Wang L, Morrison C, Chang X, Zhang H, Li W, Liu Y, Wang Y, Liu X, Chan MW, Liu JQ, Love R, Liu CG, et al. FOXP3 is an X-linked breast cancer suppressor gene and an important repressor of the HER-2/ErbB2 oncogene. Cell. 2007; 129: 1275-86. doi: 10.1016/j.cell.2007.04.034.

55. Veldhoen M, Hocking RJ, Atkins CJ, Locksley RM, Stockinger B. TGFbeta in the context of an inflammatory cytokine milieu supports de novo differentiation of IL-17producing $\mathrm{T}$ cells. Immunity. 2006; 24: 179-89. doi: 10.1016/j.immuni.2006.01.001.

56. Zhou L, Lopes JE, Chong MM, Ivanov, II, Min R, Victora GD, Shen Y, Du J, Rubtsov YP, Rudensky AY, Ziegler SF, Littman DR. TGF-beta-induced Foxp3 inhibits $\mathrm{T}(\mathrm{H}) 17$ cell differentiation by antagonizing RORgammat function. Nature. 2008; 453: 236-40. doi: 10.1038/nature06878.

57. Langrish CL, Chen Y, Blumenschein WM, Mattson J, Basham B, Sedgwick JD, McClanahan T, Kastelein RA, Cua DJ. IL-23 drives a pathogenic T cell population that induces autoimmune inflammation. J Exp Med. 2005; 201: 233-40. doi: 10.1084/jem.20041257.

58. McKenzie BS, Kastelein RA, Cua DJ. Understanding the IL-23-IL-17 immune pathway. Trends Immunol. 2006; 27: 17-23. doi: 10.1016/j.it.2005.10.003.

59. Kim H, Kim Y, Bae S, Kong JM, Choi J, Jang M, Choi J, Hong JM, Hwang YI, Kang JS, Lee WJ. Direct Interaction of CD40 on Tumor Cells with CD40L on T Cells Increases the Proliferation of Tumor Cells by Enhancing TGF-beta Production and Th17 Differentiation. PLoS One. 2015; 10: e0125742. doi: 10.1371/journal.pone.0125742.

60. Cochaud S, Giustiniani J, Thomas C, Laprevotte E, Garbar C, Savoye AM, Cure H, Mascaux C, Alberici G, Bonnefoy N, Eliaou JF, Bensussan A, Bastid J. IL-17A is produced by breast cancer TILs and promotes chemoresistance and proliferation through ERK1/2. Sci Rep. 2013; 3: 3456. doi: 10.1038/srep03456.

61. Du JW, Xu KY, Fang LY, Qi XL. Interleukin-17, produced by lymphocytes, promotes tumor growth and angiogenesis in a mouse model of breast cancer. Mol Med Rep. 2012; 6: 1099-102. doi: 10.3892/mmr.2012.1036.
62. Coffelt SB, Kersten K, Doornebal CW, Weiden J, Vrijland K, Hau CS, Verstegen NJ, Ciampricotti M, Hawinkels LJ, Jonkers J, de Visser KE. IL-17-producing gammadelta T cells and neutrophils conspire to promote breast cancer metastasis. Nature. 2015; 522: 345-8. doi: 10.1038/ nature 14282.

63. Shi YX, Tan YT, Yuan ZY, Wang SS, Peng RJ, An X, Cao Y, Jin Y, Cai XY, Sun YL, Teng XY, Liu DG. Comparison of overall survival between the early use and delayed use of Trastuzumab therapy groups: a retrospective analysis of 128 patients with HER-2-positive advanced breast cancer. Med Oncol. 2012; 29: 39-47. doi: 10.1007/s12032-010-9798-3.

64. Li B, Perabekam S, Liu G, Yin M, Song S, Larson A. Experimental and bioinformatics comparison of gene expression between T cells from TIL of liver cancer and T cells from UniGene. J Gastroenterol. 2002; 37: 275-82.

65. Zhang L, Morgan RA, Beane JD, Zheng Z, Dudley ME, Kassim SH, Nahvi AV, Ngo LT, Sherry RM, Phan GQ, Hughes MS, Kammula US, Feldman SA, et al. Tumor-infiltrating lymphocytes genetically engineered with an inducible gene encoding interleukin-12 for the immunotherapy of metastatic melanoma. Clin Cancer Res. 2015; 21: 2278-88. doi: 10.1158/1078-0432.ccr-14-2085.

66. Ikeguchi M, Hirooka Y. Interleukin-2 gene expression is a new biological prognostic marker in hepatocellular carcinomas. Onkologie. 2005; 28: 255-9. doi: 10.1159/000084695.

67. MA EL, Abd El Fatah G, Zaghla H. IL17A gene polymorphism, serum IL17 and total IgE in Egyptian population with chronic $\mathrm{HCV}$ and hepatocellular carcinoma. Immunol Lett. 2015; 168: 240-5. doi: 10.1016/j. imlet.2015.09.004.

68. Le Gouvello S, Bastuji-Garin S, Aloulou N, Mansour H, Chaumette MT, Berrehar F, Seikour A, Charachon A, Karoui M, Leroy K, Farcet JP, Sobhani I. High prevalence of Foxp3 and IL17 in MMR-proficient colorectal carcinomas. Gut. 2008; 57: 772-9. doi: 10.1136/ gut.2007.123794.

69. Liang YJ, Lao XM, Liang LZ, Liao GQ. Genome-wide analysis of cancer cell-derived Foxp3 target genes in human tongue squamous cell carcinoma cells. Int J Oncol. 2015; 46: 1935-43. doi: 10.3892/ijo.2015.2926.

70. Recouvreux MS, Grasso EN, Echeverria PC, Rocha-Viegas L, Castilla LH, Schere-Levy C, Tocci JM, Kordon EC, Rubinstein N. RUNX1 and FOXP3 interplay regulates expression of breast cancer related genes. Oncotarget. 2016; 7: 6552-65. doi: 10.18632/oncotarget.6771.

71. Tymoszuk P, Charoentong P, Hackl H, Spilka R, MullerHolzner E, Trajanoski Z, Obrist P, Revillion F, Peyrat JP, Fiegl H, Doppler W. High STAT1 mRNA levels but not its tyrosine phosphorylation are associated with macrophage infiltration and bad prognosis in breast cancer. BMC Cancer. 2014; 14: 257. doi: 10.1186/1471-2407-14-257. 